G

OPEN ACCESS

Citation: Álvarez MY, Bú FJ, Bú

FE, Soto FM, Escobar TJ. Internal Carotid Artery Thrombosis in COVID 19: Case report. Colomb Med (Cali). 2020; 51(3):e504560 http://doi. org/10.25100/cm.v51i 3.4560

Received : 25 Jun 2020

Revised : 11 Sep 2020

Accepted : 10 Oct 2020

Published: 30 Sep 2020

Keywords:

COVID-19, SARS-CoV-2; hypercoagulability; endothelial damage; carotid thrombosis; carotid artery; occlusion

Palabras clave:

COVID-19, SARS-CoV-2;

hipercoagulabilidad; daño endotelial; trombosis carotídea; arteria carótida; oclusión

Copyright: (c) 2020 Universidad del Valle.

\title{
Internal Carotid Artery Thrombosis in COVID 19: Case report.
}

\section{Trombosis de arteria carótida interna en COVID 19: Reporte de caso}

\author{
Yadira Álvarez Moreno ${ }^{1}$, Janeth Bú Figueroa ${ }^{1}$, Efraín Bú Figueroa $^{2}{ }^{\infty}$, Marco Soto \\ Fonseca $^{3}$, Javier Escobar Torres ${ }^{3}$ \\ jetorres.9307@gmail.com
}

1 Instituto Hondureño de Seguridad Social IHSS, Tegucigalpa, Honduras, 2 Honduras Medical Center, Tegucigalpa, Honduras, 3 Universidad Nacional Autónoma de Honduras, UNAH; Tegucigalpa, Honduras.

\section{Abstract}

\section{Case description:}

37-year-old female with PCR-RT swab for COVID-19 positive, with neurological manifestation as a result of internal carotid artery occlusion.

\section{Clinical findings:}

Nasal congestion and sneezing of 5 days duration; pulsatile headache in the left hemicranium 3 days prior to admission, with intensity $6 / 10$ according to the visual analogue scale, accompanied by phosphenes, photophobia and diplopia; with subsequent developing right hemiparesis over a 26 -hour period.

\section{Treatment and result:}

She was given medical management with oral antiplatelet agents and anticoagulants (subcutaneous and oral) during his hospitalization, it was not possible to perform thrombolysis and thrombectomy due to the high risk of complications. He was discharged at 14 days, without functional limitation, symmetrical strength in upper and lower limbs, bilateral visual acuity $20 / 20$, denying headache.

\section{Clinical relevance:}

The case presented here describes a pattern in how data supporting an association between COVID-19 and stroke in young populations with or without typical vascular risk factors, sometimes with only mild respiratory symptoms, is increasing. Prospective studies are required to further evaluate this association, as well as anticoagulation studies to prevent these potentially life-threatening events

Conflict of Interest: 
The authors declare that they have no conflicts of interest in the publication of this article

Funding:

No funding has been received from private or public entities for the preparation of this document

Acknowledgements:

To collaborators: Dr. Lenin Bulnes, Dr. Melvin Castillo

Corresponding author: Javier Torres. Res. Próceres, Blv. Morazán - 11101. Tegucigalpa, Honduras. E-mail: jetorres.9307@ gmail.com

\section{Resumen}

\section{Descripción del caso:}

Mujer de 37 años con hisopado PCR-RT para COVID-19 positivo, con manifestación neurológica por oclusión de la arteria carótida interna.

\section{Hallazgos clínicos:}

Congestión nasal y estornudos de 5 días de duración; cefalea pulsátil en hemicráneo izquierdo 3 días antes del ingreso, con intensidad 6/10 según la escala visual analógica, acompañada de fosfenos, fotofobia y diplopía; con posterior desarrollo de hemiparesia derecha durante un período de 26 horas.

\section{Tratamiento y resultado:}

Se le brindó manejo médico con antiagregantes plaquetarios orales y anticoagulantes (subcutáneos y orales) durante su internación, no fue posible realizar trombólisis y trombectomía por alto riesgo de complicaciones. Fue dado de alta a los 14 días, sin limitación funcional, fuerza simétrica en miembros superiores e inferiores, agudeza visual bilateral 20/20, negando cefalea.

\section{Relevancia clínica:}

Se describe un patrón que indica cómo están aumentando los datos que apoyan una asociación entre COVID-19 y el accidente cerebrovascular en poblaciones jóvenes con o sin factores de riesgo vascular típicos, a veces con solo síntomas respiratorios leves. Se requieren estudios prospectivos para evaluar más a fondo esta asociación, así como estudios de anticoagulación para prevenir estos eventos potencialmente mortales.

\section{Introduction}

COVID-19 is a new disease caused by the SARS-CoV-2 virus (Severe Acute Respiratory Syndrome Coronavirus 2) that is spreading rapidly around the world ${ }^{1}$. COVID-19 has affected more than 39.2 million people and caused more than 1,100,000 deaths worldwide ${ }^{2}$ and although it is primarily a respiratory disease, scientific studies suggest that it can lead to a hypercoagulable state and thrombotic complications ${ }^{3,4}$.

Recent publications from China, France and New York raise the possibility that COVID-19 may increase the risk of ischemic stroke ${ }^{5,6}$.

Neutrophil activation is an important clinical feature in COVID-19; being the first to respond to the invasion of pathogens and tissue damage that mediate the death of pathogens by oxidative explosion and phagocytosis ${ }^{7}$. Activated neutrophils that fail to extravasculate are partially degranulated in the circulation ${ }^{8}$ which, due to their low floating densities, are known as low-density granulocytes. These cells are also found in immune-mediated inflammatory diseases ${ }^{9}$. They are particularly prone to expel their contents, with antimicrobial agents stored in their granules, a process known as neutrophil extracellular trap formation (NET) ${ }^{10,11}$.

Excessive NET formation leads to the formation of aggregates ${ }^{12}$ that occlude vessels ${ }^{13}$ and ducts ${ }^{14}$, causing damage to tissues. With inflammation, prothrombotic coagulopathy and endothelial injury as mechanisms involved ${ }^{15}$. 
Acute viral infections, oxidative stress, hypoxia, and turbulent blood flow have been established to act as triggers that increase the short-term risk of ischemic stroke and other arterial thrombotic events, such as myocardial infarction ${ }^{15}$.

We report a case of a 37-year-old female patient with a positive PCR-RT swab for COVID-19, with a neurological manifestation as a result of internal carotid artery occlusion.

This case report follows the CARE Guidelines ${ }^{16}$.

\section{Narrative}

37-year-old woman, environmental health technician; with a history of rheumatic fever during childhood, hypertension and smoking for 2 years; denies traumatic events and use of oral contraceptives. She presented to the hospital emergency center, reporting nasal congestion and sneezing of 5 days duration; pulsatile headache in the left hemicranium 3 days prior to admission, with intensity $6 / 10$ according to the visual analogue scale, accompanied by phosphenes, photophobia and diplopia; with subsequent developing right hemiparesis over a 26-hour period; who delayed seeking emergency care for fear of COVID-19. She denies fever, anosmia, ageusia, seizures, cough, chest or abdominal pain. When presented to the hospital, the score on the National Institutes of Health Stroke Scale (NIHSS) was 8 (scores range from 0 to 42 , with higher numbers indicating greater severity of stroke).

Upon admission, BP: 130/80 mmHg, HR: 62 beats per minute, RR: 18 breaths per minute, $\mathrm{SatO}_{2}: 98 \%$, T: $37.3^{\circ} \mathrm{C}$. Visual acuity decreased in the left eye (20/40), eye movements and visual fields preserved, without alterations to the fundus. Left carotid pulse of decreased intensity compared to contralateral. There were no signs of pulmonary and / or cardiac involvement. Decreased strength and reflexes in the right half body (4/5), lucid, oriented. Rest of physical examination within normal parameters.

\section{Evolution}

Complementary tests are requested (Table 1); Simple phase brain tomography, without evidence of focal and / or diffuse lesions. However, the USG Carotid Doppler describes the absence of flow in the left internal carotid artery (ICA) due to the presence of echogenic material immediately at the bifurcation of the common carotid artery (Fig. 1 Carotid Doppler Ultrasound video).

Low molecular weight heparin (Enoxaparin $60 \mathrm{mg}$ subcutaneous every 12 hours) is started at a therapeutic dose, antiplatelet therapy (Acetylsalicylic Acid 100mg and Clopidogrel 75 $\mathrm{mg}$ orally every day) and statins (Rosuvastatin $40 \mathrm{mg}$ orally every day). Due to exposure to positive cases of COVID-19 in her working place, previous mild respiratory symptoms and the presence of ICA thrombosis; RT-PCR for SARS-CoV-2 was requested; with positive result.

The case was evaluated by the neurology, vascular surgery and neurosurgery services; who consider that, given the findings described and that; the hours of evolution at the time of diagnosis, the patient is not a candidate for fibrinolysis or thrombectomy, due to the high risk of later complications. Therefore, it was recommended to continue with the established medical management.

On his fourteenth day hospital, there was a clear improvement in his symptoms, maintaining standing, without functional limitation, symmetrical strength in upper and lower limbs, bilateral 20/20 visual acuity, denial of headache.

The patient was discharged with secondary preventive medication, consisting of: Rivaroxaban $20 \mathrm{mg}$ every day, Rosuvastatin $20 \mathrm{mg}$ every day, Amlodipine $10 \mathrm{mg}$ every day, Acetylsalicylic acid $100 \mathrm{mg}$ every day, Clopidogrel $75 \mathrm{mg}$ every day and Esomeprazole $40 \mathrm{mg}$ every day. One month after the onset of symptoms, a control evaluation was performed, in which no visual or 
Table 1. Complementary tests

\begin{tabular}{|c|c|c|}
\hline Hematological & Medical admission & Reference Values \\
\hline Hemoglobin & 11.8 & $(12-16 \mathrm{~g} / \mathrm{dL})$ \\
\hline Hematocrit & 38 & $(38-47 \%)$ \\
\hline Platelets & 234,000 & $(150,000-500,000)$ \\
\hline White blood cells & 8,500 & $(5,000-10,000)$ \\
\hline Neutrophils & 4,000 & $(2,000-7,000)$ \\
\hline Lymphocytes & 3,600 & $(800-4,600)$ \\
\hline $\mathrm{TP}$ & 17.4 & $(10.7-14.1 \mathrm{sec})$ \\
\hline TTP & 34.0 & $(23.6-36.5)$ \\
\hline INR & 1.34 & \\
\hline \multicolumn{3}{|l|}{ Metabolic / Renal } \\
\hline Glucose & 89 & $(74-100 \mathrm{mg} / \mathrm{dL})$ \\
\hline BUN & 6 & $(6-23 \mathrm{mg} / \mathrm{dL})$ \\
\hline Creatinine & 0.8 & $(0.5-0.9 \mathrm{mg} / \mathrm{dL})$ \\
\hline Total cholesterol & 139 & $(30-200 \mathrm{mg} / \mathrm{dL})$ \\
\hline HDL cholesterol & 57 & $(45-65 \mathrm{mg} / \mathrm{dL})$ \\
\hline LDL cholesterol & 70 & $(20-100 \mathrm{mg} / \mathrm{dL})$ \\
\hline Triglycerides & 123 & $(30-200 \mathrm{mg} / \mathrm{dL})$ \\
\hline TGO (AST) & 14 & $(0-32 \mathrm{U} / \mathrm{L})$ \\
\hline TGP (ALT) & 8 & $(0-41 \mathrm{U} / \mathrm{L})$ \\
\hline Sodium & 144 & $(135-145 \mathrm{mmol} / \mathrm{L})$ \\
\hline Potassium & 4.4 & $(3.5-5.1 \mathrm{mmol} / \mathrm{L})$ \\
\hline Chlorine & 108 & $(98-110 \mathrm{mEq} / \mathrm{L})$ \\
\hline \multicolumn{3}{|l|}{ Perfil Inmune } \\
\hline ANA & 0.2 & Negative $<1$, Positive $>1$ \\
\hline C-ANCA & 1.25 & Negative $<5$, Positive $>5$ \\
\hline P-ANCA & 1.08 & Negative $<5$, Positive $>5$ \\
\hline IgM anticardiolipin & 1.025 & Negative $<7$, Positive $>7$ \\
\hline IgG anticardiolipin & 0.282 & Negative $<0.8$, Positive $>1.2$ \\
\hline Complement C3 & 97 & $(90-180 \mathrm{mg} / \mathrm{dL})$ \\
\hline Complement C4 & 33 & $(10-40 \mathrm{mg} / \mathrm{dL})$ \\
\hline \multicolumn{3}{|l|}{ Otros } \\
\hline RT-PCR SARS-CoV2 & Positive & \\
\hline ESR & 54.00 & $(0-20 \mathrm{~mm} / \mathrm{h})$ \\
\hline PCR & 68.75 & $(1-5 \mathrm{mg} / \mathrm{dL})$ \\
\hline Procalcitonin & 0.035 & $(0-0.5 \mathrm{ng} / \mathrm{mL})$ \\
\hline D-dimer & NA* & \\
\hline Fibrinogen & NA * & \\
\hline $\mathrm{LDH}$ & 454 & $(50-250 \mathrm{U} / \mathrm{L})$ \\
\hline IL-6 & NA* & \\
\hline Ferritin & NA * & \\
\hline Troponins & 3.0 & Negative $<14 \mathrm{ng} / \mathrm{L}$ \\
\hline Protein C & 1.83 & $(1.67-3.16 \mathrm{mg} / \mathrm{dL})$ \\
\hline Protein S & 57.48 & $(56.7-167.9 \%)$ \\
\hline EKG & \multicolumn{2}{|l|}{ Within normal parameter } \\
\hline Chest X-ray & \multicolumn{2}{|l|}{ Within normal parameter } \\
\hline Echocardiogram & \multicolumn{2}{|c|}{ Slight fibrosis and calcification of the mitral valve, without stenosis. Type I diastolic dysfunction. LVEF: $48 \%$} \\
\hline Chest CT & \multicolumn{2}{|l|}{ Within normal parameter } \\
\hline Brain CT & \multicolumn{2}{|l|}{ Within normal parameter } \\
\hline Brain MRI & \multicolumn{2}{|l|}{ See description in Figure 2.} \\
\hline Angio- CT of the Neck and Thorax & \multicolumn{2}{|c|}{ Absence of contrast medium from the internal carotid artery. Rest of normal study. } \\
\hline Angio-IRM & \multicolumn{2}{|l|}{ See description in Figure 2.} \\
\hline
\end{tabular}

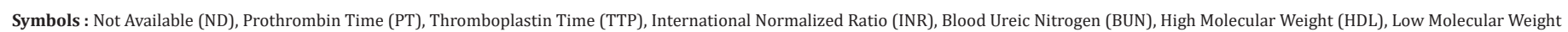

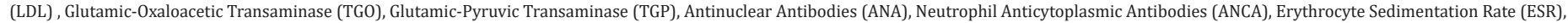

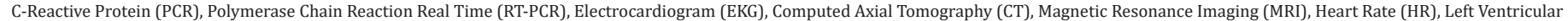
Ejection Fraction (LVEF). 


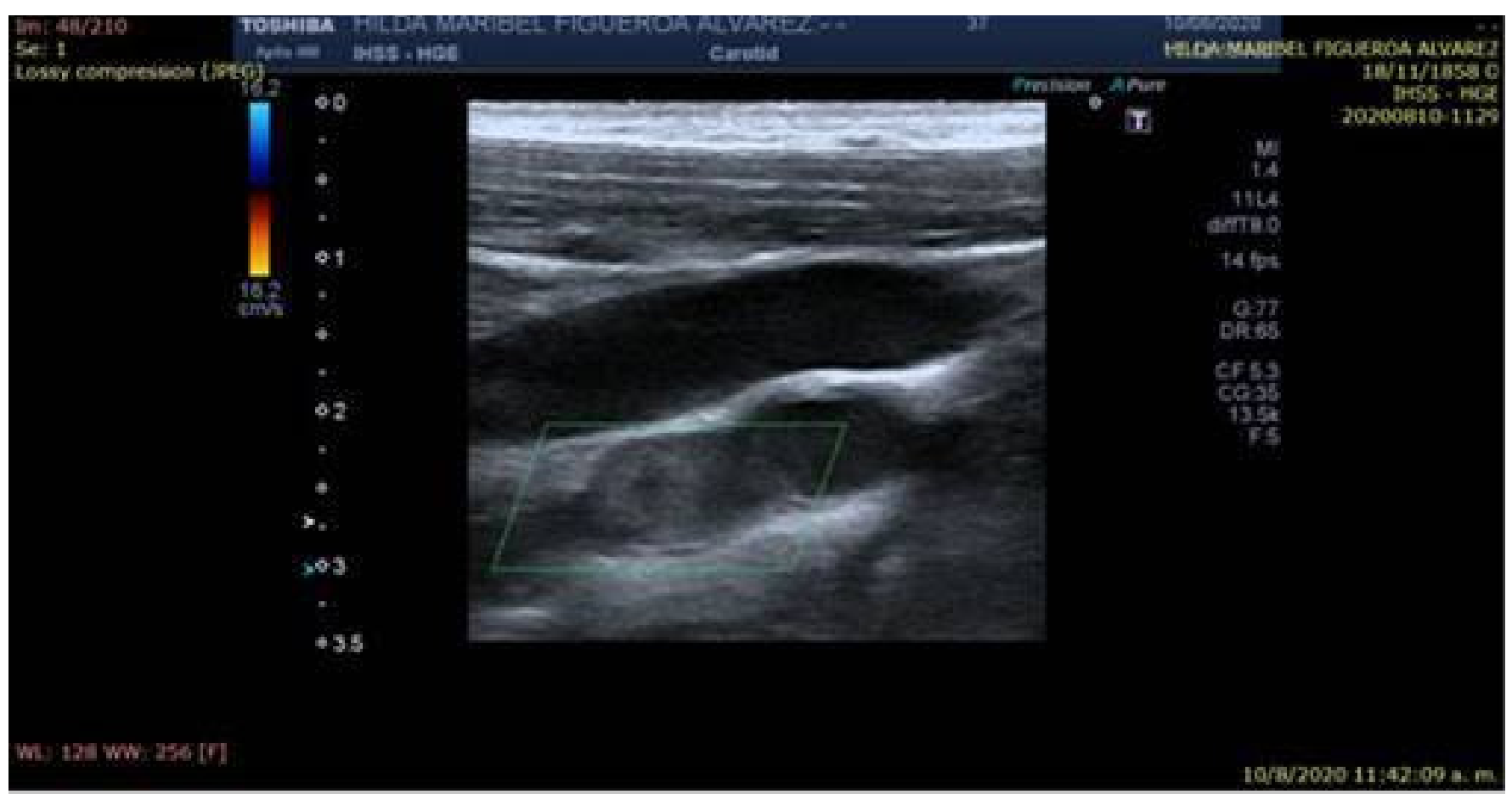

Figure 1.Carotid Doppler Ultrasound. No evidence of flow when applying color or spectral Doppler due to the presence of echogenic material inside. (Green box)

functional limitation was evidenced. A follow up Brain Magnetic Angio-Resonance Imaging (MRI-Angio) is described in Figure 2.

The antiplatelet drugs were withdrawn from their treatment due to adverse effects associated with them (bleeding in the gums) and proton pump inhibitors, and the internal medicine outpatient was called back in 15 days for reevaluation.

\section{Forecast}

Due to the persistence of the occlusion of the internal carotid artery and the lack of alternatives for the intervention of this process and the latent risk of formation of new sites of occlusion; the prognosis is uncertain. For this reason, constant vigilance and monitoring will set the tone.

To this day, the patient continues on oral anticoagulants; rest at home and has not merited further hospitalization.

\section{Diagnostics (Table 2)}

\section{Patient perspective}

I consider myself an active and hardworking woman. I started with a general malaise that limited my functions at home. Getting to the Honduran Social Security Institute was very difficult due to the COVID pandemic; I was afraid of getting infected. It was a surprise for me and my family when the doctors gave me the results of my tests. I got better as the days went by. Doctors have been monitoring my progress at home.

\section{Discussion}

The endgame of COVID-19 typically involves a cytokine storm, a phlogistic phenomenon fueled by well-understood positive feedback loops that govern cytokine production and overwhelm counter-regulatory mechanisms ${ }^{17}$, manifested in patients with moderate and 


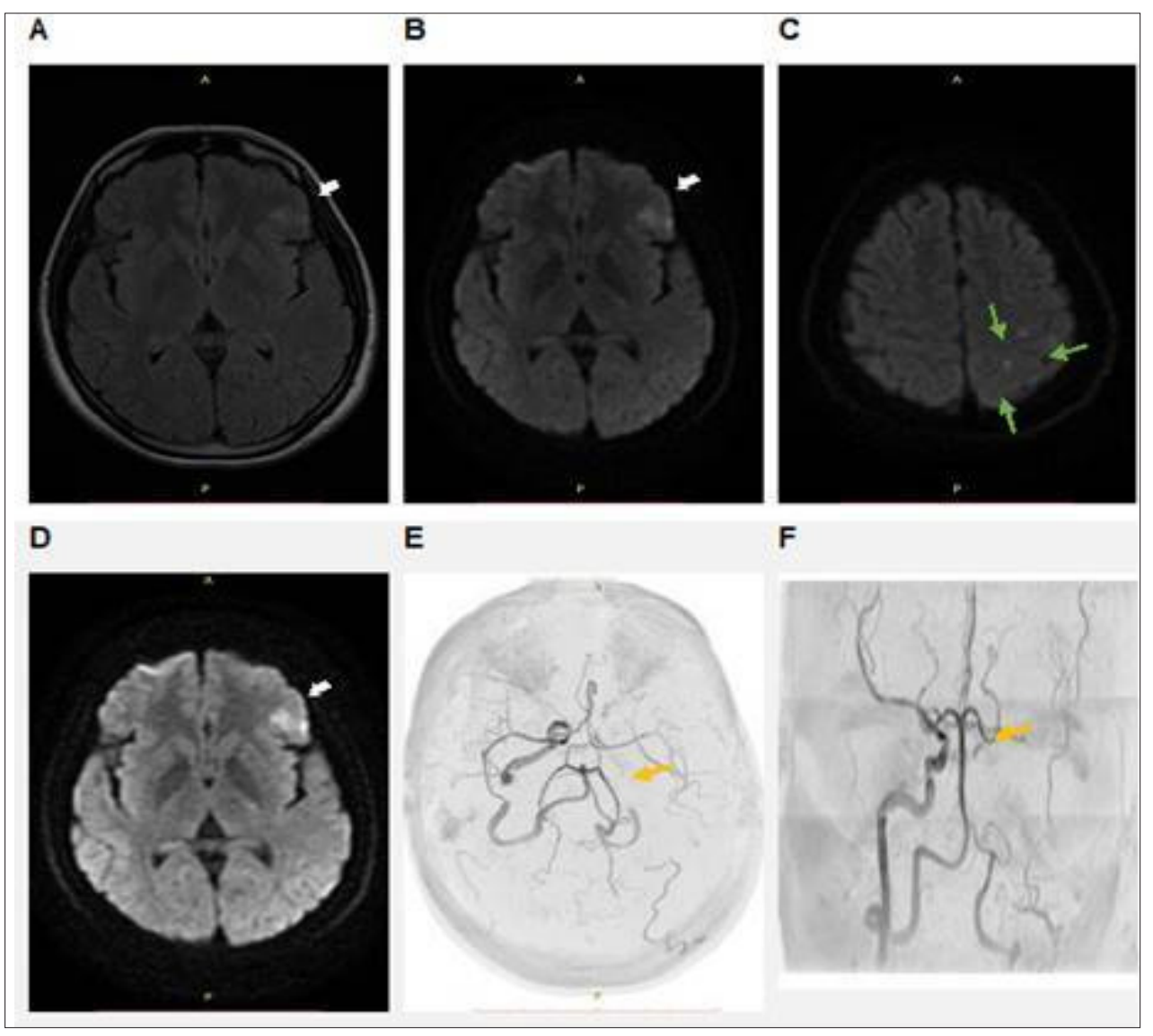

Figure 2. A. Axial FLAIR Magnetic Resonance Imaging (MRI), small left lateral frontal cortical hyperintense area. B, C. Diffusion MRI, confirms acute ischemic cerebrovascular event, left frontal and small lacunar ischemic events in the left parietal lobe. D. Control Axial MRI, shows a hyperintense lesion in the left frontal region and a small sequel lesion in the left parietal lobe. E, F. Angio -Persistently 3D-TOF, no signal left middle left internal carotid artery and cerebral artery.

severe stages of the illness. Our patient with COVID-19, confirmed with RT-PCR; it debuted with a neurological manifestation associated with thrombosis of the ICA.

This pattern of severe inflammation is a reason for attention in the field of vascular neurology because it has been shown an increased risk of cardiovascular complications. These findings were mainly attributed to the hyperinflammatory response with localized vascular compromise ${ }^{18}$.

The hypercoagulable state and endothelial dysfunction as complications of COVID $19^{19}$ and the sum of risk factors such as smoking, hypertension, dyslipidemia and sedentary lifestyle, increase the risk of thromboembolic complications of the great vessels, as evidenced in the case presented.

A multicenter study of 26 patients with COVID-19 and ischemic or hemorrhagic events reported that $27 \%$ were younger than 50 years ${ }^{20}$. In addition, the report indicated that two of the 15 patients with great vessel stroke were younger than 50 years and no prior stroke risk factors.

Mohamud et al. ${ }^{21}$, described a series of 6 COVID-19 patients with acute ischemic stroke due to an intraluminal thrombus of the carotid artery. Six patients with a mean age of 65.8 years (range, 55-78 years) were included. All patients had a history of vascular risk factors, such as diabetes (83\%), hyperlipidemia (100\%), and smoking (17\%).

Oxley et al. ${ }^{5}$, published a series of cases of COVID 19 patients with cerebrovascular event in those under 50 years of age, in which the case of a previously healthy 33-year-old female patient with a history of headache, cough and chills stands out. of a week of evolution, who 
Table 2. Pruebas complementarias

\begin{tabular}{|c|c|c|c|}
\hline Date & Type & Value & Unit \\
\hline $2020-09-02$ & PTT (partial thromboplastin time) & 34 & seconds \\
\hline 2020-09-02 & Neutrophils & 4,000 & thousand cells/cubic mm \\
\hline 2020-09-02 & AST (aspartate aminotransferase) & 14 & $\mathrm{U} / \mathrm{L}$ \\
\hline 2020-09-02 & Creatinine & 0.8 & $\mathrm{mg} / \mathrm{dL}$ \\
\hline 2020-09-02 & Lymphocytes & 3,600 & thousand cells/cubic mm \\
\hline 2020-09-02 & Sodium & 144 & $\mathrm{mmol} / \mathrm{L}$ \\
\hline 2020-09-02 & Glucose & 89 & $\mathrm{mg} / \mathrm{dL}$ \\
\hline 2020-09-02 & Platelet count & 234,000 & thousand cells/cubic mm \\
\hline $2020-09-02$ & Cholesterol, HDL & 57 & $\mathrm{mg} / \mathrm{dL}$ \\
\hline 2020-09-02 & WBC (total white blood cells) & 8,500 & thousand cells/cubic mm \\
\hline 2020-09-02 & Triglycerides & 123 & $\mathrm{mg} / \mathrm{dL}$ \\
\hline 2020-09-02 & Cholesterol, LDL & 70 & $\mathrm{mg} / \mathrm{dL}$ \\
\hline $2020-09-02$ & Potassium & 4.4 & $\mathrm{mmol} / \mathrm{L}$ \\
\hline 2020-09-02 & Cholesterol, total & 139 & $\mathrm{mg} / \mathrm{dL}$ \\
\hline $2020-09-02$ & Hb (hemoglobin) & 11.8 & $\mathrm{~g} / \mathrm{dL}$ \\
\hline 2020-09-02 & ALT (alanine aminotransferase) & 8 & $\mathrm{U} / \mathrm{L}$ \\
\hline 2020-09-02 & Chloride & 108 & $\mathrm{mEq} / \mathrm{L}$ \\
\hline 2020-09-02 & BUN (blood urea nitrogen) & 6 & $\mathrm{mg} / \mathrm{dL}$ \\
\hline 2020-09-02 & PT (prothrombin time) & 17.4 & seconds \\
\hline 2020-09-02 & Hct (hematocrit) & 38 & $\%$ \\
\hline 2020-09-03 & ESR (erythrocyte sedimentation rate) & 5.4 & $\mathrm{~mm} / 1 \mathrm{st}$ hour \\
\hline 2020-09-03 & CRP (C-reactive protein) & 68.75 & $\mathrm{mg} / \mathrm{dL}$ \\
\hline 2020-09-03 & Troponin I & 3 & $\mathrm{ng} / \mathrm{L}$ \\
\hline $2020-09-03$ & LDH (lactate dehydrogenase) & 454 & $\mathrm{U} / \mathrm{L}$ \\
\hline 2020-09-04 & RT-PCR SARS-CoV-2 (COVID-19) & positive & \\
\hline
\end{tabular}

later presented progressive dysarthria with numbness and weakness in the left arm and left leg during a period of 28 hours and NIHSS 19 points. Imaging studies revealed partial ischemic infarction in the territory of the right middle cerebral artery with a partially occlusive thrombus in the right carotid artery at the cervical bifurcation. Echocardiographic and magnetic resonance imaging of the head and neck did not reveal the origin of the thrombus.

Although it was not counted in a timely manner due to logistical limitations, with common markers of acute inflammation such as IL-6, ferritin and D-dimer; alteration of CRP, VES and LDH was found.

Additionally, to rule out other common etiologies of thrombogenesis in the patient, laboratory studies for autoimmunity were performed, all of them were negative.

The concept of COVID-19 as an endothelial disease provides a unifying pathophysiological picture of this aggressive infection and also a framework for a rational treatment strategy, at a time when we have a really modest evidence base to guide our therapeutic attempts and confront this pandemic ${ }^{17}$.

\section{Conclusion}

Data supporting an association between COVID-19 and stroke in young populations with or without typical vascular risk factors, sometimes with only mild respiratory symptoms, is increasing.

Prospective studies are required to further evaluate this association, as well as anticoagulation studies to prevent these potentially life-threatening events.

Keep in mind that, otherwise healthy young patients, who have a stroke during the pandemic, the diagnosis of COVID-19 should be thoroughly investigated. In contrast, in patients with mild respiratory symptoms of COVID-19, a low threshold for stroke investigation should be maintained if they exhibit neurological symptoms. 


\section{Informed consent}

The informed consent of the patient was requested prior to writing the manuscript. It authorizes the use of the information in your clinical record, safeguarding your personal identity data.

\section{References}

1. Zhu N, Zhang D, Wang W, Li X, Yang B, Song J, Zhao X, et al. Equipo de investigación e investigación del nuevo coronavirus de China. un nuevo coronavirus de pacientes con neumonía en China, 2019. N Engl J Med. 2020; 382 (8): 727-733. doi: 10.1056 / NEJMoa2001017.

2. Organización Mundial de la Salud. Informes de situación del coronavirus (COVID-2019); 2020. citado: 20 de agosto de 2020. https://www.who.int/emergencies/diseases/novel-coronavirus-2019/situation-reports/

3. Zhang Y, Xiao M, Zhang S, Xia P, Cao W, Jiang W, et al. Coagulopatía y anticuerpos antifosfolípidos en pacientes con COVID-19. N Engl J Med. 2020; 382 (17): e38. doi: 10.1056 / NEJMc2007575

4. Klok FA, Kruip MJHA, Van der Meer NJM, Arbous MS, Gommers DAMPJ, Kant KM, et al. Incidencia de complicaciones trombóticas en pacientes críticos de UCI con COVID-19. Thromb Res. 2020; 191: 145-147. doi: 10.1016 / j.thromres.2020.04.013.

5. Oxley TJ, Mocco J, Majidi S, Kellner CP, Shoirah H, Singh IP, et al. Accidente cerebrovascular de vasija grande como característica de presentación de Covid-19 en los jóvenes. N Engl J Med. 2020; 382 (20): e60. doi: 10.1056 / NEJMc2009787.

6. Yaghi S, Ishida K, Torres J, Mac Grory B, Raz E, Humbert K, et al. SARS-CoV-2 y accidente cerebrovascular en un sistema de salud de Nueva York. Carrera. 2020; 51 (7): 2002-2011. doi: 10.1161 / STROKEAHA.120.030335.

7. Jenne CN, Liao S, Singh B. Neutrófilos: primeros respondedores multitarea de inmunidad y homeostasis tisular. Cell Tissue Res. 2018; 371 (3): 395-397. doi: 10.1007 / s00441-018-2802-5.

8. Adrover JM, Aroca-Crevillén A, Crainiciuc G, Ostos F, Rojas-Vega Y, Rubio-Ponce A, et al. El desarme programado del proteoma de neutrófilos reduce la magnitud de la inflamación. Nat Immunol. 2020; 21 (2): 135144. doi: 10.1038 / s41590-019-0571-2.

9. Carmona-Rivera C, Zhao W, Yalavarthi S, Kaplan MJ. Las trampas extracelulares de neutrófilos inducen disfunción endotelial en el lupus eritematoso sistémico mediante la activación de la metaloproteinasa 2 de la matriz. Ann Rheum Dis. 2015; 74 (7): 1417-24. doi: 10.1136 / annrheumdis-2013-204837.

10. Brinkmann V, Reichard U, Goosmann C, Fauler B, Uhlemann Y, Weiss DS, Weinrauch Y, Zychlinsky A. Las trampas extracelulares de neutrófilos matan bacterias. Ciencias. 2004; 303 (5663): 1532-5. doi: 10.1126 / science.1092385.

11. Boeltz S, Amini P, Anders HJ, Andrade F, Bilyy R, Chatfield S, et al. A NET o no a NET: opiniones actuales y estado de la ciencia sobre la formación de trampas extracelulares de neutrófilos. Diferencia de muerte celular. 2019; 26 (3): 395-408. doi: 10.1038 / s41418-018-0261-x.

12. Schauer C, Janko C, Muñoz LE, Zhao Y, Kienhöfer D, Frey B, et al. Las trampas extracelulares de neutrófilos agregadas limitan la inflamación al degradar citocinas y quimiocinas. Nat Med. 2014; 20 (5): 511 7. doi: $10.1038 / \mathrm{nm} .3547$.

13. Jiménez-Alcázar M, Rangaswamy C, Panda R, Bitterling J, Simsek YJ, Long AT, et al. Las ADNasas del huésped previenen la oclusión vascular por trampas extracelulares de neutrófilos. Ciencias. 2017; 358 (6367): 1202-1206. doi: 10.1126 / science.aam8897. 
14. Leppkes M, Maueröder C, Hirth S, Nowecki S, Günther C, Billmeier U, et al. La cromatina de neutrófilos descondensada externalizada ocluye los conductos pancreáticos e impulsa la pancreatitis. Nat Commun. 2016; 7: 10973. doi: 10.1038 / ncomms10973.

15. Boehme AK, Esenwa C, Elkind MS. Factores de riesgo de accidente cerebrovascular, genética y prevención. Circ Res. 2017; 120 (3): 472-495. doi: 10.1161 / CIRCRESAHA.116.308398.

16. Riley DS, Barber MS, Kienle GS, Aronson JK, von Schoen-Angerer T, Tugwell P, et al. Explicaciones y elaboraciones de CARE 2013: Directrices para la presentación de informes de casos. J Clin Epi. 2017; 89: 218235. doi: 10.1016 / jclinepi.2017.04.026.

17. Libby P, Lüscher T. COVID-19 es, en definitiva, una enfermedad endotelial. Europ Heart J. 2020; 41 (32): 3038-3044. Doi: 10.1093 / eurheartj / ehaa623

18. Madjid M, Safavi-Naeini P, Solomon SD, Vardeny O. Efectos potenciales de los coronavirus en el sistema cardiovascular: una revisión. JAMA Cardiol. 2020; 5 (7): 831-840. doi: 10.1001 / jamacardio.2020.1286.

19. Zhou F, Yu T, Du R, Fan G, Liu Y, Liu Z, et al. Curso clínico y factores de riesgo para la mortalidad de pacientes adultos hospitalizados con COVID-19 en Wuhan, China: un estudio de cohorte retrospectivo. Lanceta. 2020; 395 (10229): 1054-1062. doi: 10.1016 / S0140-6736 (20) 30566-3.

20. Taylor BES, Khandelwal P, Rallo MS, Patel P, Smith L, Sun H, et al . Resultados y espectro de eventos neurovasculares importantes entre pacientes con COVID-19: una experiencia de 3 centros. Neurocirugía Abierta. 2020; 1 (3): okaa008. doi: 10.1093 / neuopn / okaa008.

21. Mohamud AY, Griffith B, Rehman M, Miller D, Chebl A, Patel SC, et al . Trombo de arteria carótida intraluminal en COVID-19: ¿otro peligro de tormenta de citocinas ?. Soy J Neuroradiol. 2020; 41 (9): 16771682. doi: 10.3174 / ajnr.A6674. 